Canadian

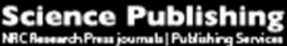

Biochemistry and Cell Biology

Biochimie et biologie cellulaire

\title{
Hyperbaric oxygen enhances neutrophil apoptosis and their clearance by monocyte-derived macrophages
}

\begin{tabular}{|r|l|}
\hline Journal: & Biochemistry and Cell Biology \\
\hline Manuscript ID: & bcb-2014-0157.R2 \\
\hline Manuscript Type: & Article \\
\hline Date Submitted by the Author: & $26-$ May-2015 \\
\hline Complete List of Authors: & $\begin{array}{l}\text { Almzaiel, Anwar; Plymouth University, School of Biological Sciences } \\
\text { Billington, Richard; Plymouth University, School of Biological Sciences } \\
\text { Smerdon, Gary; DDRC Healthcare, } \\
\text { Moody, John; Plymouth University, School of Biological Sciences }\end{array}$ \\
\hline Keyword: & hyperbaric oxygen, neutrophil, macrophage, apoptosis \\
\hline &
\end{tabular}

\section{SCHOLARONE}

Manuscripts 


\section{Hyperbaric oxygen enhances neutrophil}

\section{apoptosis and their clearance by monocyte-}

\section{derived macrophages}

Anwar J. Almzaiel ${ }^{\mathrm{a}}$, Richard Billington ${ }^{\mathrm{a}}$, Gary Smerdon ${ }^{\mathrm{b}}$, A. John Moody ${ }^{\mathrm{a}}$

${ }^{a}$ Centre for Research in Translational Biomedicine, Plymouth University, Drake Circus, Plymouth PL4 8AA, UK

${ }^{\mathrm{b}}$ DDRC Healthcare, Plymouth Science Park, Plymouth PL6 8BU, UK

Address for correspondence: Dr A.J. Moody, School of Biological Sciences, Plymouth University, Drake Circus, Plymouth PL4 8AA, UK 


\begin{abstract}
Neutrophil apoptosis and clearance by macrophages are essential for wound healing. Evidence suggests that hyperbaric oxygen (HBO) exposure may enhance neutrophil apoptosis, but HBO effects leading to neutrophil clearance by macrophages are still unclear. In the current study, bovine neutrophils and monocyte-derived macrophages (MDM $\Phi$ ) were co-cultured under $\mathrm{HBO}\left(97.9 \% \mathrm{O}_{2}, 2.1 \% \mathrm{CO}_{2}\right.$ at 2.4 ATA), hyperbaric normoxia $\left(8.8 \% \mathrm{O}_{2}\right.$ at 2.4 ATA), normobaric hyperoxia $\left(95 \% \mathrm{O}_{2}, 5 \% \mathrm{CO}_{2}\right)$, normoxia (air) and normobaric hypoxia $\left(5 \% \mathrm{O}_{2}, 5 \% \mathrm{CO}_{2}\right)$. Phagocytosis of fresh and $22 \mathrm{~h}$-aged neutrophils by MDMФ was increased after HBO pre-treatment, assessed using flow cytometry and light microscopy. Enhanced clearance of neutrophils was accompanied by an increase in $\mathrm{H}_{2} \mathrm{O}_{2}$ levels following HBO pretreatment with up regulation of IL-10 (anti-inflammatory cytokine) mRNA expression in LPS-stimulated MDM $\Phi$ that had ingested aged neutrophils. TNF- $\alpha$ (pro-inflammatory cytokine) gene expression did not change in LPS-stimulated MDMФ that had ingested fresh or aged neutrophils after HBO, pressure and hyperoxia. These findings suggest that HBOactivated MDMФ participate in the clearance of apoptotic cells. Uptake of neutrophils by MDMФ exposed to HBO may contribute to resolution of inflammation, because HBO induced up-regulation of IL-10 mRNA expression.
\end{abstract}

Keywords: hyperbaric oxygen, neutrophils, macrophages, apoptosis 


\section{Introduction}

Neutrophils are key players in wound healing; large numbers migrate to wound sites during the acute inflammatory phase of wound healing, their numbers being controlled by their rates of infiltration and apoptosis (Simon 2003). Upon activation, neutrophils release reactive oxygen species (ROS) and enzymes that are stored in granules (Henson and Johnston 1987). These are essential for their antimicrobial function, but can also cause damage if the inflammatory response is prolonged. Hence, apoptosis is important in preventing release of inflammatory mediators from neutrophils and allowing them to be cleared safely by macrophages (Savill et al. 1989). Apoptotic cells undergo specific surface changes, e.g. exposure of phosphatidylserine (PS) on the outer leaflet of the plasma membrane, which lead to their recognition and ingestion by phagocytes (Fadok et al. 2001a). PS exposure is essential for the uptake of apoptotic cells by macrophages (Fadok et al. 2001b, Fadok et al. 1992).

Hypoxia is a key feature of chronic wounds, where destruction of vasculature in the wound and high oxygen consumption by inflammatory cells such as neutrophils, result in low oxygen levels (Tandara and Mustoe 2004). Under hypoxic conditions neutrophil apoptosis and subsequent clearance are markedly inhibited (Mecklenburgh et al. 2002, Walmsley et al. 2005). Prolonged hypoxia coupled with bacterial colonization leads to release of inflammatory cytokines from inflammatory cells at wound sites, prolonging the inflammation (Wolcott et al. 2008). Increased levels of the pro-inflammatory cytokines TNF- $\alpha$ and IL-6, but decreased levels of IL-10, are characteristic of non-healing wounds, where a major source of these cytokines is macrophages (Werner and Grose 2003). The successful phagocytosis of apoptotic cells results in suppression of pro-inflammatory cytokines and the progress of wound healing (Lee et al. 1993, Khanna et al. 2010). 
Hyperbaric oxygen (HBO) therapy is the administration of $100 \%$ oxygen by inhalation at pressures greater than one atmosphere (1 ATA) for 60-90 min, repeated once or twice daily (Gill and Bell 2004). HBO has been found to increase apoptosis in HL-60 cells, Jurkat cells and lymphocytes (Weber et al. 2009a, Ganguly et al. 2002), as well as in neutrophil-like cells derived from HL-60 cells (Almzaiel et al. 2013). An immunosuppressive effect of HBO treatment on the inflammatory process in ischaemic wounds and trauma has been demonstrated (Al-Waili and Butler 2006, Zhang et al. 2008) together with decreased levels of TNF- $\alpha$ and IL-1 $\beta$ secreted by monocytes and macrophages collected from rats or from human peripheral blood after stimulation with LPS (Lahat et al. 1995, Benson et al. 2003). Hence, the effects $\mathrm{HBO}$ on clearance of apoptotic cells by macrophages may be potentially important in the resolution of inflammation and hence in the progress of wound healing.

Given this background, the current study aimed to determine whether HBO-induced apoptosis was able to enhance neutrophil clearance by MDM $\Phi$ in a non-inflammatory process. In order to elucidate the effects of $\mathrm{HBO}$ on resolution of inflammation and the potential involvement of ROS-mediated apoptosis in this process, monocyte-derived macrophages (MDMФ) from bovine blood were used as a macrophage model to phagocytose neutrophils.

\section{Materials and methods}

\section{$\underline{2.1 \text { Tissue culture reagents }}$}

Dulbecco's Modified Eagle Medium (DMEM) and Hank's Balanced Salt Solution (HBSS) without $\mathrm{Ca}^{2+}$ and $\mathrm{Mg}^{2+}$ were obtained from Gibco Liga Technologies (Paisley, UK). Fetal calf serum was purchased from Lonza (Wokingham, UK) and was heat inactivated $\left(56{ }^{\circ} \mathrm{C}, 1\right.$ h) before addition to the media (10\%). 


\subsection{Bovine blood}

Samples of blood were obtained from twenty Holstein cows (age $220 \pm 60 \mathrm{~d}, 12$ female, 8 male) slaughtered at Gage's Abattoir (Gage's Farm, Ashburton, Devon, UK). The animals had no clinical symptoms of disease.

\section{$\underline{2.3 \text { Cell isolation and culture }}$}

Both monocytes and neutrophils were isolated from bovine blood as previously described (Quinn et al. 2007). The method involved lysis of contaminating red blood cells (RBC) combined with density centrifugation in Histopaque ${ }^{\circledR} 1077 / 1119$ to obtain relatively pure suspensions of neutrophils and monocytes. Briefly, $50 \mathrm{ml}$ of blood was collected into Vacutainer $^{\mathrm{TM}}$ tubes containing EDTA. Whole blood was centrifuged at $500 \times g$ for $10 \mathrm{~min}$ at $4{ }^{\circ} \mathrm{C}$, and then Platelet Rich Plasma (PRP) was removed. The buffy coat, found at the plasmared blood cell interface, was collected, washed and re-suspended in DMEM at a density of 4 $\times 10^{6}$ cells $\mathrm{ml}^{-1}$. Cell suspensions (monocytes/lymphocytes, $0.5 \mathrm{ml}$ per well) were plated into individual wells in 24 well plates and incubated for $1 \mathrm{~h}\left(37^{\circ} \mathrm{C}, 5 \% \mathrm{CO}_{2}\right.$, balance air) to allow monocyte adherence. Following $1 \mathrm{~h}$ incubation, tissue culture medium was removed and nonadherent cells including contaminating lymphocytes were removed by washing twice with DMEM.

The remaining $\mathrm{RBC}$ and leucocytes from earlier (mostly neutrophils) were split between three $50 \mathrm{ml}$ centrifuge tubes, diluted with $5 \mathrm{ml}$ of cold distilled water and gently mixed for about $2 \mathrm{~min}$ in order to lyse the RBC. Immediately after this period $2.5 \mathrm{ml}$ of $0.2 \% \mathrm{NaCl}$ were added to restore isotonicity. The suspension was centrifuged at $200 \times g$ for $5 \mathrm{~min}$ at 4 ${ }^{\circ} \mathrm{C}$, after which the supernatant was removed. These steps were repeated twice if necessary to lyse remaining RBCs. To obtain highly purified and functional neutrophils, the crude neutrophil suspension was layered above $10 \mathrm{ml}$ of Histopaque ${ }^{\circledR}$ 1077/1119 mixture (Sigma- 
Aldrich, Poole, UK) and centrifuged at $440 \times g$ for $25 \mathrm{~min}$ at room temperature. The neutrophils form a pellet and any contaminating mononuclear cells remain at the sample/medium interface. The neutrophil pellet was washed by resuspending in $50 \mathrm{ml} \mathrm{HBSS}$ and centrifuging at $600 \times \mathrm{g}$ for $10 \mathrm{~min}$ at room temperature. Purified neutrophils were resuspended in $5 \mathrm{ml}$ of DMEM medium.

\section{$\underline{2.4 \text { Hyperbaric oxygen and pressure control treatments }}$}

Hyperbaric chambers were supplied by DDRC Healthcare, Plymouth, UK) and connecting hoses from Pressure Lines Ltd (Plymouth, UK). Different gas mixes were kindly prepared by DDRC Healthcare (Plymouth, UK). To achieve hyperbaric oxygen conditions, the chambers were flushed for $4 \mathrm{~min}$ at $31 \mathrm{~min}^{-1}$ with $97.9 \% \mathrm{O}_{2}, 2.1 \% \mathrm{CO}_{2}$, and then pressurized to 2.4 atmosphere absolute (ATA) over $2 \mathrm{~min} ; 2.1 \% \mathrm{CO}_{2}$ at 2.4 ATA was used to achieve a $\mathrm{CO}_{2}$ concentration equivalent to $5 \% \mathrm{CO}_{2}$ at $1 \mathrm{ATA}$ in a conventional incubator. To investigate the effect of pressure alone, cells were treated with $8.8 \% \mathrm{O}_{2}, 2.1 \% \mathrm{CO}_{2}$, balance $\mathrm{N}_{2}$ at 2.4 ATA; $8.8 \% \mathrm{O}_{2}$ was used such that the $\mathrm{O}_{2}$ concentration would be equivalent to $21 \%$ at 1 ATA. For normobaric hyperoxic or hypoxic treatments, cells were flushed with gas mixtures containing $95 \% \mathrm{O}_{2}, 5 \% \mathrm{CO}_{2}$ or $5 \% \mathrm{O}_{2}, 5 \% \mathrm{CO}_{2}$ balance $\mathrm{N}_{2}$, respectively, for $2-4 \mathrm{~min}$ at a rate of $41 \mathrm{~min}^{-1}$ in gas-tight plastic boxes $(21.5 \mathrm{~cm} \times 21.5 \mathrm{~cm} \times 11 \mathrm{~cm})$. This achieved the correct concentration inside the chamber box, based on direct measurement with an oxygen meter (PCE-007, Dwyer Instruments Ltd, High Wycombe, UK). Control cell cultures for each experiment were placed in similar boxes under $21 \% \mathrm{O}_{2}, 5 \% \mathrm{CO}_{2}$, balance $\mathrm{N}_{2}$, at 1 ATA. Treatments were continued for $90 \mathrm{~min}$, after which the cells were removed (pressure chambers were decompressed over 8-10 min) and centrifuged for $5 \mathrm{~min}$ at $400 \mathrm{~g}$ followed by

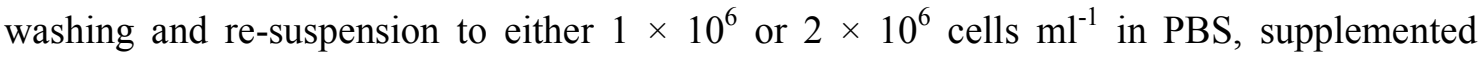
RPMI-1640 medium or Hank's Balanced Salt Solution (HBSS) as appropriate. Cells were 
used immediately in the assays described below. All treatments were carried out at room temperature.

\subsection{Generation of monocyte-derived macrophages (MDMФ)}

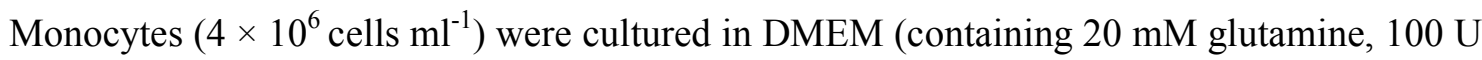
$\mathrm{ml}^{-1}$ penicillin and $10 \mu \mathrm{g} \mathrm{ml}^{-1}$ streptomycin) and $10 \%(\mathrm{v} / \mathrm{v})$ heat-inactivated bovine autologous serum (derived from platelet-rich plasma by re-calcification with $20 \mathrm{mM} \mathrm{CaCl} 2$ for $1 \mathrm{~h}$ at $37{ }^{\circ} \mathrm{C}$ (in glass tubes) and plated $(0.5 \mathrm{ml}$ per well) in 24 -well plates. The cells were incubated under $5 \% \mathrm{CO}_{2}$ (balance air). The medium was replaced every three days and the cells were used for experiments within seven days of plating.

\section{$\underline{2.6 \text { Induction of apoptosis }}$}

Following isolation from peripheral blood, neutrophils were cultured at $37{ }^{\circ} \mathrm{C}$ under $5 \% \mathrm{CO}_{2}$

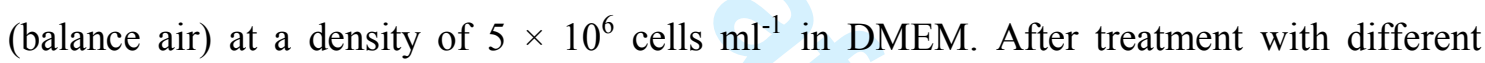
oxygen or pressure conditions (Section 2.4), neutrophils were either used fresh or aged by transferring $0.5 \mathrm{ml}$ aliquots of cell suspension in DMEM supplemented with $10 \%(\mathrm{v} / \mathrm{v})$ autologous serum to each well of a 24 -well plate and incubating for $22 \mathrm{~h}$, at $37{ }^{\circ} \mathrm{C}$ under $5 \%$ $\mathrm{CO}_{2}$ (balance air), during which time a proportion of the cells underwent apoptosis (Savill et al, 1989a). Cells were harvested at the indicated times and resuspended in DMEM (serum free) and analysed immediately.

\subsection{Assay for cell viability}

Samples of each suspension of neutrophils (50 $\mu \mathrm{l}$ of $10^{6}$ cells $\mathrm{ml}^{-1}$ in supplemented RPMI1640) were mixed with $50 \mu 1$ of $0.4 \%$ trypan blue solution and incubated at room temperature for 5 min. Total and non-viable (i.e. trypan blue stained) cells were counted using a haemocytometer. 


\section{$\underline{2.8 \mathrm{MTT} \text { assay }}$}

Neutrophils were resuspended in RPMI-1640 at $10^{6}$ cells $\mathrm{ml}^{-1}$. Samples of each cell suspension $(100 \mu 1)$ were placed in the wells of 96-well plates and then $10 \mu \mathrm{l}$ of MTT $(5 \mathrm{mg}$ $\mathrm{ml}^{-1}$ in PBS; Sigma, Poole, UK) was added to each well and incubated for $2-3 \mathrm{~h}$ at $37{ }^{\circ} \mathrm{C}$. After incubation, $100 \mu \mathrm{l}$ DMSO was added to each well and incubated for 20-30 min at room temperature to solubilize any formazan product. The plates were read on a VersaMax plate reader (Molecular Devices, Sunnyvale, CA, USA) at $540 \mathrm{~nm}$ (Vistica et al. 1991).

\subsection{Morphological assessment of cell apoptosis}

Neutrophils were first washed in supplemented RPMI-1640 medium after which cytocentrifuge preparations of $10^{6}$ cells, made up to $100 \mu \mathrm{l}$ in medium, were prepared using a Shandon Cytospin centrifuge (Cheshire, UK, $400 \mathrm{~g}$ for $5 \mathrm{~min}$ ). Slides were stained using 20\% modified Wright-Giemsa stain (pH 7.0, Sigma, Poole, UK) for $10 \mathrm{~min}$, washed with three changes of distilled water and air dried thoroughly before evaluation. Morphological changes characteristic of apoptosis were assessed microscopically using a $\times 100$ oil-immersion objective (Olympus BH, Japan). Triplicate slides were prepared for each condition, and at least 500 cells per slide were counted. This method has been previously demonstrated to correlate closely with other parameters of apoptosis (Savill et al. 1989). Apoptotic cells were characterized by nuclear condensation and fragmentation, while membrane integrity was maintained.

$\underline{2.10 \text { Assay of neutrophil apoptosis by annexin } \mathrm{V} \text { binding and propidium iodide with flow }}$ cytometry

The annexin V/PI cell apoptosis assay is dependent upon the exposure of PS on the surface of apoptotic cells (van Engeland et al. 1998). The conjugation with fluorescein isothiocyanate 
(FITC) allows identification of annexin V binding by flow cytometry, and is often used in conjunction with another stain such as propidium iodide (PI). Neutrophils were pelleted by centrifugation at $400 \times g$ for $5 \mathrm{~min}$. This was performed either immediately after isolation or after aging the neutrophils. Cells were then resuspended in DMEM, after which the percentage of apoptotic neutrophils was determined by flow cytometry. Cells were washed in cold PBS and resuspended at a concentration 1-2 $\times 10^{6}$ cells in annexin V binding buffer. The cells in $100 \mu \mathrm{l}$ of annexin V binding buffer were pelleted, before addition of FITC-conjugated annexin V (5 $\mu \mathrm{l}$; eBioscience, Hatfield, UK). The tubes were incubated on ice in the dark for $15 \mathrm{~min}$, and then washed and resuspended in $100 \mu \mathrm{l}$ of annexin V binding buffer, after which $5 \mu \mathrm{l}$ of PI $\left(1 \mu \mathrm{g} \mathrm{ml}^{-1}\right)$ was added. Flow cytometric analysis of cell suspensions was performed by using an Arial $^{\mathrm{TM}}$ II FACS (excitation $520 \mathrm{~nm}$ and emission $620 \mathrm{~nm}$, Becton-Dickinson, San Jose, USA) within $1 \mathrm{~h}$ of staining. Data for 10000 events were analysed for each sample using Becton-Dickinson FACS Diva software. Neutrophils were initially gated by their characteristic forward scatter (FSC) and side scatter (SSC) profiles. Cell debris was gated out before analysis on the basis of FSC and SSC properties.

\section{$\underline{2.11 \text { Assay of DNA fragmentation in apoptotic neutrophils }}$}

Determination of apoptotic cell death was confirmed by detection of DNA laddering using gel electrophoresis (Counis and Torriglia 2000, Filipski et al. 1990). Briefly, apoptotic neutrophils $\left(2 \times 10^{6}\right.$ cells $\left.\mathrm{ml}^{-1}\right)$ were collected and washed with PBS, and the DNA was extracted with a Wizard ${ }^{\circledR}$ genomic DNA purification kit (Promega Corp., Madison, WI, USA) according to the manufacturer's instructions. DNA samples were stored at $-80{ }^{\circ} \mathrm{C}$ until use. DNA fragmentation in neutrophils was assessed qualitatively by agarose gel electrophoresis. Extracted DNA samples were loaded on to a $1 \%$ agarose gel, containing SYBR $^{\circledR}$ Safe $(1 \times)$ and TAE for 1 to $2 \mathrm{~h}$ at $90 \mathrm{~V}$. The gel was visualized under UV a using a 
transilluminator (UVItec Limited, England). Gel images were evaluated for typical of low molecular weight DNA fragments separated in size by 180-200 base pairs, a hallmark of apoptosis (Wyllie et al. 1980). DNA fragment sizes were determined by using DNA size markers in the range 0.5 to $12 \mathrm{~kb}$ (New England Biolabs, Hitchin, UK).

\subsection{Detection of phagocytosis of apoptotic cells by flow cytometry}

For the flow cytometric phagocytosis assay, a previously described method was applied (Rossi et al. 2006). Neutrophils were used as targets to assess MDMФ phagocytosis by flow cytometry. Neutrophils were labelled with the fluorescent dye $\operatorname{Tracker}^{\mathrm{TM}}$ Green (5chloromethyl fluorescein diacetate, CMFDA, Invitrogen, Paisley, UK) at a final concentration of $2 \mu \mathrm{g} \mathrm{ml}^{-1}\left(1 \mu \mathrm{lof} 1 \mathrm{mg} \mathrm{ml}^{-1}\right.$ stock solution per $1 \times 10^{6}$ neutrophils) and seeded in 24-well plates at $5 \times 10^{6}$ cells $\mathrm{ml}^{-1}$ for $15 \mathrm{~min}$ at $37^{\circ} \mathrm{C}$ (under $5 \% \mathrm{CO}_{2}$, balance air). Target cells were then collected for co-culture with phagocytes.

For co-culture, $0.5 \mathrm{ml}$ of suspension containing $5 \times 10^{6}$ target cells was added to each MDMФ-containing well (which had been washed with $\mathrm{HBSS}$ without $\mathrm{Ca}^{2+}$ and $\mathrm{Mg}^{2}$ following 6-8 days differentiation) after which the cells were exposed to different oxygen and pressure conditions (Section 2.4). Finally they were co-incubated at $37{ }^{\circ} \mathrm{C}$ under $5 \% \mathrm{CO}_{2}$ (balance air) for $1 \mathrm{~h}$. After incubation, non-ingested neutrophils and medium were removed from the wells by washing with PBS. The remaining cells, i.e. MDMФ with ingested neutrophils, were detached from the plates using $300 \mu 1$ of $0.25 \%$ trypsin/ $1 \mathrm{mM}$ EDTA for 15 min at $37{ }^{\circ} \mathrm{C}$ followed by $15 \mathrm{~min}$ at $4{ }^{\circ} \mathrm{C}$, washed and resuspended in PBS and transferred to FACS tubes. In order to ensure that all the MDMФ were removed from wells, plates were examined by light microscopy. Cells were analysed using an Arial ${ }^{\mathrm{TM}}$ II FACS (BectonDickinson, San Jose, USA; excitation 492 nm/emission $517 \mathrm{~nm}$ ) using FACS Diva software ${ }^{\circledR}$. MDMФ were initially gated by their characteristic forward scatter (FSC) and side scatter 
(SSC) profiles, after which quadrants were set up based on matched controls including unstained MDMФ alone and neutrophils stained with Tracker ${ }^{\mathrm{TM}}$ Green alone.

Neutrophils and MDMФ that had ingested apoptotic neutrophils were separated (gated) by FSC and SSC profile, and at least 10000 events were counted in each sample. Uningested neutrophils were identified by the combination of their green fluorescence due to Tracker $^{\mathrm{TM}}$ green labelling and their relatively smaller size (FSC) when compared with the MDMФ. MDMФ populations were gated based on FSC and SSC characteristics, MDM $\Phi$ that had ingested neutrophils and hence showed green fluorescence were deemed to have ingested apoptotic neutrophils. All results are reported as the percentage of total cells stained.

\section{$\underline{2.13 \text { Detection of phagocytosis of apoptotic cells by light microscopy }}$}

In order to assess phagocytosis by microscopy, MDMФ were incubated with neutrophils as described in Section 2.12. Following phagocytosis, the medium was removed from each well and the wells washed three times with ice-cold PBS to remove all non-engulfed neutrophils. Next, the cells were fixed with $2.5 \%$ glutaraldehyde in PBS for 10 min and stained for MPO activity using one part of $0.1 \mathrm{mg} \mathrm{ml}^{-1}$ dimethoxybenzidine as substrate to one part of freshly prepared $0.03 \%(\mathrm{v} / \mathrm{v}) \mathrm{H}_{2} \mathrm{O}_{2}$ in PBS. To achieve an appropriate level of staining, cells were incubated at $37{ }^{\circ} \mathrm{C}$ for $60 \mathrm{~min}$ at room temperature. Finally, uptake of apoptotic neutrophils by MDMФ was assessed by light microscopy (Nikon, Japan). MPO activity leads to formation of a soluble yellow-brown product detectable by light microscopy (Hart et al., 1997). MDM $\Phi$ that had ingested neutrophils were MPO positive, while MDM $\Phi$ which had not were MPO negative. Five hundred cells per each of three replicate wells were examined. The percentage of MDM $\Phi$ that had ingested neutrophils was calculated.

\subsection{Assay of extracellular hydrogen peroxide}


A horseradish peroxidase (HRP)-linked assay using homovanillic acid was used to measure production of $\mathrm{H}_{2} \mathrm{O}_{2}$ by neutrophils. Briefly, $100 \mu \mathrm{l}$ of cell suspension in HBSS, containing $10^{6}$ cells $\mathrm{ml}^{-1}$ was added to each well of a 96 -well plate. Then $100 \mu 1$ of HBSS containing 200 $\mu \mathrm{M}$ homovanillic acid, $10 \mathrm{U} \mathrm{ml}^{-1} \mathrm{HRP}$ (P8375, Sigma, Poole, UK) and $100 \mathrm{ng} \mathrm{ml}^{-1} \mathrm{PMA}$ were added per well, and the fluorescence measured after 120 min at $37^{\circ} \mathrm{C}$ using a CytoFluor II fluorescence microplate reader (PerSeptive Biosystems, Framingham, USA; excitation 320 nm/emission $420 \mathrm{~nm})$. A standard curve $\left(0-100 \mu \mathrm{M} \mathrm{H}_{2} \mathrm{O}_{2}\right)$ was used to determine the $\mathrm{H}_{2} \mathrm{O}_{2}$ concentration in each well (Baggiolini et al. 1986).

\section{$\underline{2.15 \text { Measurement of TNF- } \alpha \text { and IL-10 expression using qPCR }}$}

MDMФ were cultured at $5 \times 10^{6}$ cells $\mathrm{ml}^{-1}$ and stimulated with LPS $\left(100 \mathrm{ng} \mathrm{ml}^{-1}\right)$ for $2 \mathrm{~h}$ before addition of neutrophils, and co-culture for $1 \mathrm{~h}$ at $37{ }^{\circ} \mathrm{C}$. They were then washed in PBS and pelleted. Total RNA was extracted using a GeneElute ${ }^{\mathrm{TM}}$ mammalian total RNA miniprep kit (Sigma, Poole, UK), cDNA synthesised and qPCR for TNF- $\alpha$ (primers: forward GGTGGCCCCTCCATCAACAGC, reverse GGCCACGAGGGCATTGGCATA) and IL-10 (primers: forward CCTGGAAGAGGTGATGCCACAGG, reverse CCTTCTCCACCGCCTTGCTCT) genes was carried out. For the housekeeping gene, $\beta$-actin (primers: forward, CGCCATGGATGATGATATTGC, reverse: AAGCCGGCCTTGCACAT) was used. Neutrophils cultured alone (fresh or 22 h-aged) were also stimulated with LPS (100 ng $\mathrm{ml}^{-1}$ ) for $2 \mathrm{~h}$ before total RNA was isolated and processed for qPCR as described above.

\section{$\underline{2.16 \text { Statistical Analysis }}$}

Data are expressed as means \pm SEM. Statistical analysis was carried out using Statgraphics Centurion XVI software (Stat Point Technologies, Inc.). Following the Andersen-Darling and Levene tests, data were analysed by two-way ANOVAs (parametric data) or Kruskal-Wallis (non-parametric). After two-way ANOVA, if the interaction was non-significant, Tukey's 
test was used. If the interaction was significant, the data for fresh and $22 \mathrm{~h}$-aged neutrophils were further analysed separately by one-way ANOVA followed by Tukey's. A $P$ value of $<$ 0.05 is considered significant throughout.

\section{Results}

\section{$\underline{3.1 \text { Effect of oxygen treatments on neutrophil viability }}$}

Cell 'viability' using the trypan blue and MTT assays was assessed for fresh neutrophils and $22 \mathrm{~h}$-aged neutrophils (Figs 1A and B). A significant interaction between time and treatment was found for trypan blue and MTT (two-way ANOVA, $P<0.05$ ). There was a statistically significant decrease in the percentage cell viability in 22 h-aged neutrophils (two-way ANOVA, $P<0.00005$ for trypan blue and MTT) compared with fresh neutrophils post different treatments. A significant decrease in viability was found for both fresh and $22 \mathrm{~h}$ aged neutrophils pre-exposed to $\mathrm{HBO}$, pressure, hyperoxia compared with normoxia (oneway ANOVA, $P<0.05$ for trypan blue and MTT). Hypoxia pre-treatment had no significant effect on the percentage cell viability in fresh and 22 h-aged neutrophils (trypan blue and MTT) compared to normoxia (Figs 1A and B).

\section{$\underline{3.2 \text { Effect of oxygen treatments on apoptosis }}$}

The effects of different oxygen treatments on neutrophil apoptosis were assessed using several assays: FITC-annexin V/PI staining via flow cytometry, morphology using Giemsa staining and DNA fragmentation. Dual staining with FITC-labelled Annexin V and PI showed a significant decrease in the percentage of live cells and an increase in early apoptotic cells in fresh neutrophils assayed immediately after HBO or pressure treatments (one-way ANOVA, $P=0.045$ and 0.020 , respectively) compared to normoxia (Fig. 2A). Both hyperoxia and hypoxia pre-treatments showed no significant effect on the levels of live cells 
and early apoptotic cells. Also, there was no significant difference between treatments in the percentage of the cell population that was late apoptotic or dead (Fig. 2A). The same pattern was seen with neutrophils aged for $22 \mathrm{~h}$ post oxygen treatments. There was a significantly higher proportion of early apoptotic cells (Kruskal-Wallis, $P=0.030$ ) and a corresponding decrease in live cells (one-way ANOVA, $P=0.0002$ ) post-HBO and pressure treatments compared to normoxia (Fig. 2B), but not following hyperoxia and hypoxia treatments. $22 \mathrm{~h}$ aged neutrophils also demonstrated no significant difference in the percentage of late apoptotic and dead cells (one-way ANOVA, $P>0.05$ ).

To further assess the effects of different treatments on neutrophil apoptosis, morphological changes were analysed by light microscopy using modified Wright-Giemsa staining (Figs 3A and B). These changes include membrane blebbing but not loss of integrity, nuclear and cytoplasmic condensation and fragmentation, and formation of apoptotic bodies. There was a significant increase in morphological changes that are typically observed during apoptosis in 22 h-aged neutrophils compared to fresh neutrophils post different treatment (two-way ANOVA, $P<0.005)$. A significant increase was observed in morphological changes relating to cell apoptosis in both fresh and $22 \mathrm{~h}$-aged neutrophils after exposure to $\mathrm{HBO}$, pressure and hyperoxia (two-way ANOVA, $P<0.00005$; Fig. 3B), compared with normoxia. As expected, the hypoxia treatment significantly decreased apoptosis of both fresh and $22 \mathrm{~h}$-aged neutrophils compared with normoxia (Fig. 3B).

The cleavage of chromatin into multi-nucleosome sized fragments also indicates that cell death has occurred via apoptosis. Figs 4A and B show the DNA ladders observed on agarose gels for fresh and $22 \mathrm{~h}$-aged neutrophils after treatments. The amount of fragmented DNA in 22 h-aged-neutrophils increased compared to fresh neutrophils. The only characteristic DNA profile detected in fresh neutrophils was immediately after HBO treatment confirming cell death via apoptosis (Fig. 4A). The degree of DNA fragmentation was more marked in $22 \mathrm{~h}$ - 
aged neutrophils after HBO, with less genomic DNA visible (Fig. 4B). However, lower but detectable DNA fragmentation was observed in 22 h-aged neutrophils after pressure, hyperoxia and hypoxia treatments compared to normoxia (Fig. 4B).

\section{$\underline{3.3 \text { Effects of oxygen treatments on phagocytosis of neutrophils }}$}

The percentage of MDM $\Phi$ that had ingested neutrophils labelled with $\operatorname{Tracker}^{\mathrm{TM}}$ green was assessed by flow cytometric analysis and the results are presented in Fig. 5. Phagocytosis of 22 h-aged neutrophils by MDMФ was significantly increased (two-way ANOVA, $P<0.005$ ) compared with fresh neutrophils. Immediately after HBO and pressure treatments, MDMФ co-cultured with fresh and 22 h-aged neutrophils were characterized by a significantly increased uptake of neutrophils (two-way ANOVA, $P<0.00005$ ) compared to normoxia (Fig. 5). No differences in MDMФ phagocytosis of fresh and 22 h-aged neutrophils were observed after hyperoxia and hypoxia pre-treatments compared with normoxia (Fig. 5).

Phagocytosis of apoptotic cells by MDM $\Phi$ was further confirmed by light microscopic examination of cytocentrifuged preparations of $M D M \Phi$ after the phagocytosis assay had been performed. This analysis clearly showed the presence of MPO-positive cells inside MDMФ (Fig. 6A). Quantification of \% phagocytosis confirmed the FACS data in that MDMФ were shown to be more able to uptake $22 \mathrm{~h}$-aged neutrophils than fresh neutrophils following different treatments (two-way ANOVA, $P=0.009$ ). In common with the flow cytometric results, MDMФ exhibited a higher capacity to phagocytose fresh and $22 \mathrm{~h}$-aged neutrophils immediately after HBO and pressure treatments (two-way ANOVA, $P<0.00005$ ) compared with normoxia. Exposure to hypoxia did not produce a significant change in percentage phagocytosis of neutrophils compared with normoxia (Figs 6 A and B).

3.4 Oxidants mediate neutrophil clearance by MDMФ: possible effects of HBO 
The $\mathrm{H}_{2} \mathrm{O}_{2}$ concentrations in the supernatants from PMA-stimulated fresh or $22 \mathrm{~h}$-aged neutrophils cultured alone or after co-culture with MDMФ are shown in Fig. 7A. $\mathrm{H}_{2} \mathrm{O}_{2}$ levels showed a significant increase in fresh neutrophils and 22 h-aged neutrophils post treatment with HBO, pressure and hyperoxia (two-way ANOVA, $P<0.00005$ ) compared with normoxia. In contrast, hypoxia pre-treatment had no effect on $\mathrm{H}_{2} \mathrm{O}_{2}$ levels in fresh and $22 \mathrm{~h}$ aged neutrophils (Fig. 7A) compared with normoxia.

$\mathrm{HBO}$, pressure and hyperoxia pre-treatments gave a significant increase in $\mathrm{H}_{2} \mathrm{O}_{2}$ levels in MDMФ that had ingested fresh or $22 \mathrm{~h}$-aged neutrophils (two-way ANOVA, $P<0.00005$ ) compared with normoxia. No treatment effects were observed on $\mathrm{H}_{2} \mathrm{O}_{2}$ levels in co-cultures of MDMФ with fresh or $22 \mathrm{~h}$-aged neutrophils after pre-treatment to hypoxia (Fig. 7B).

$\underline{3.5 \text { Effects of HBO on TNF- } \alpha \text { and IL-10 gene expression on co-culture of neutrophils with }}$ $\underline{\text { MDMФ }}$

It has been proposed that clearance of apoptotic neutrophils results in non-inflammatory response (Fox et al. 2010). Therefore the functional consequences of phagocytosis of apoptotic neutrophils by $\operatorname{MDM} \Phi$ were investigated by measuring the cytokine gene expression (TNF- $\alpha$ and IL-10) of fresh neutrophils, 22 h-aged neutrophils and MDMФ cocultured with neutrophils following different oxygen treatments and stimulation with $100 \mathrm{ng}$ $\mathrm{ml}^{-1}$ LPS. As already demonstrated (Section 3.3), it is presumed that some ingestion of apoptotic neutrophils by MDMФ will have occurred during the co-culture. For fresh and 22 h-aged neutrophils cultured alone, the data are normalised against fresh neutrophils under normoxia (Figs 8A and B) while co-culture data are normalised against MDMФ cultured alone (Figs $8 \mathrm{C}$ and D). Note that for the co-culture experiments mRNA was extracted from the mixture of cell types and so the different contributions of the MDM $\Phi$ and neutrophils to the observed mRNA levels cannot be determined. 
Although hyperoxia, pressure and HBO caused a significant increase in TNF- $\alpha$ expression in fresh and 22 h-aged neutrophils incubated alone (Fig. 8A), there were no increases when these neutrophils were co-cultured with MDMФ except in the case of fresh neutrophils and hyperoxia (Fig. 8C) (Kruskal-Wallis, $P<0.05$ ). For IL-10, HBO caused a small increase in gene expression for both fresh and aged neutrophils incubated alone, whereas hyperoxia and pressure caused a slight decrease in expression in fresh neutrophils (Fig. 8B). However, when aged neutrophils were co-cultured with increase in IL-10 expression, whereas there was no effect when fresh neutrophils were cocultured with MDMФ (Fig. 8D). 


\section{Discussion}

The ability of MDMФ to phagocytose neutrophils is an important step in the resolution of inflammation and the progress of wound healing (Serhan and Savill 2005). The hypothesis behind the present study was that oxidative stress induced by hyperbaric oxygen (HBO) contributes to the apoptosis of neutrophils and that this augments clearance by macrophages through their recognition of the apoptotic neutrophils. Flow cytometric analysis using FITCannexin V/PI (Fig. 2); assessment of morphological changes (Fig. 3); and DNA fragmentation (Fig. 4) all showed that pre-exposure of neutrophils to HBO or pressure for 90 min induced apoptosis in both fresh neutrophils and neutrophils that had been aged for $22 \mathrm{~h}$ after the exposure, with the greater response detected in aged neutrophils. This is the first demonstration that HBO induces apoptosis in bovine neutrophils, although previous studies have shown that HBO induces apoptosis in cultured cells, e.g. Jurkat-T cells (Ganguly et al. 2002, Chen et al. 2007), HL-60 cells (Ganguly et al. 2002), NCI-H929 cells (Chen et al. 2007) and murine thymocytes (Ganguly et al. 2002). It is worth bearing in mind that there may be significant functional differences between phagocytic cells from different mammalian species, so issues in extrapolation from the behaviour of bovine phagocytes to human phagocytes cannot be precluded.

Having established that HBO induced apoptosis of neutrophils, the mechanisms involved were investigated. One possibility is that HBO-induced apoptosis is a function of oxygen partial pressure. Pre-treatment with HBO has been shown to up-regulate NADPH oxidase activity and caspase-3/7 activity, which suggests that HBO-induced ROS production may enhance apoptosis, resulting in the formation of pro-apoptotic substances in the cells or in the medium (Matsunami et al. 2011). It is well known that mitochondrial-generated ROS are involved in the release of cytochrome $c$ and other pro-apoptotic proteins from mitochondria, so HBO-induced apoptosis could be via the mitochondrial pathway (Weber et al. 2009a). 
Exogenous $\mathrm{H}_{2} \mathrm{O}_{2}$ produced by the activity of xanthine oxidase or glucose oxidase induces apoptosis in neutrophils (Rollet-Labelle et al. 1998) and also, endogenous production of ROS has been shown to be involved in the activation of apoptosis by Fas and TNF- $\alpha$ receptors (Kasahara et al. 1997, Scheel-Toellner et al. 2004, van den Berg et al. 2001). Consistent with this, after pre-exposure to $\mathrm{HBO}$ or pressure, $\mathrm{H}_{2} \mathrm{O}_{2}$ levels produced by both fresh and aged neutrophils were increased, which in turn could have enhanced neutrophil apoptosis. This is also in agreement with our previous study that indicated an increase in ROS production and apoptosis in neutrophil-like cells (derived from HL-60 cells) post 90 min HBO exposure (Almzaiel et al. 2013).

Other mechanisms could explain the FITC-annexin V/PI assay results. Annexin V binds to PS that has been externalised on surface of cells undergoing apoptosis. Pressure could have caused a deformation which led to conformational changes that might enhance PS translation to the outer leaflet of the cell membrane (van Engeland et al. 1997, Mateo et al. 2002). Consistent with this, we found an increase in apoptosis and a decrease in viability of fresh and aged neutrophils after pre-exposure to both pressure alone and HBO.

An important functional characteristic of macrophages is their ability to ingest apoptotic cells. The present data clearly indicate that HBO enhanced ingestion of apoptotic neutrophils by monocyte-derived macrophages (MDMФ). MDMФ showed a higher level of ingestion of fresh neutrophils after HBO exposure than after other treatments, which is consistent with the previously noted effect of $\mathrm{HBO}$ resulting in a high percentage of early apoptotic neutrophils. However, aged neutrophils were recognised and ingested to a greater extent than fresh neutrophils after HBO, pressure and hyperoxia treatments. There were discrepancies between the percentages of phagocytic MDMФ observed via flow cytometry and via morphology, although the pattern was similar. This may in part have arisen because the data presented are 
from separate experiments with cells derived from different animals, and the assays were not performed in parallel.

The clearance of apoptotic cells from an inflamed wound site takes place via a pathway that involves exposure of PS on the outer leaflet of the cell membrane (Fadok et al. 2001a), but the mechanisms of PS externalization are not fully characterized. In this study, PS expression on the outer membrane layer was detected by the measurement of FITC-conjugated annexin $\mathrm{V}$ using flow cytometry. HBO and pressure treatments showed an increase in exposure of PS in fresh and aged neutrophils which was perhaps recognized by $\operatorname{MDM} \Phi$ via multiple phagocyte receptors including PS receptors, vitronectin receptors $\left(\alpha_{v} \beta_{3}\right)$ and CD36. Shiratsuchi and Basson (2004) found that increasing extracellular pressure to $20 \mathrm{~mm} \mathrm{Hg}$ above ambient pressure for $2 \mathrm{~h}$ stimulated phagocytosis of serum-opsonized latex beads by PMA-stimulated THP-1 macrophages. These effects seemed to be due to inhibition of FAKY397 autophosphorylation and consequent inhibition of ERK activation. Similarly, the same authors demonstrated that exposure to pressure also increased the phagocytosis of latex beads by monocytes that were isolated from human blood or MDMФ prepared by culturing with autologous unheated serum. These effects were mediated by p38 MAPKs, which are activated by cellular stress and microbial phagocytosis in macrophages (Bertram et al. 1997). In our study, the pressure utilized during HBO may have contributed to the increase in phagocytosis percentage as hyperoxia alone did not have the same effect.

It is also possible that oxidants may be responsible for an increase in phagocytosis of apoptotic cells, due to ROS generation during HBO treatment. The present study suggests that functional NADPH oxidase may have a role in PS exposure in activated neutrophils as well as for their clearance by MDMФ. In the present study, a significant increase in $\mathrm{H}_{2} \mathrm{O}_{2}$ was observed immediately after HBO and pressure exposure in fresh and aged neutrophils. Furthermore, the increase was correlated with enhanced neutrophil apoptosis, the process 
necessary for clearance of neutrophils. PS exposure on apoptotic neutrophils can occur as a result of $\mathrm{H}_{2} \mathrm{O}_{2}$ production, enabling their uptake and clearance by macrophages (Hampton et al. 2002). Arroyo et al. (2002) found that NADPH oxidase-induced oxidative stress in neutrophil-like cells initiated apoptosis, and subsequent recognition and phagocytosis of these cells via pathways dependent on oxidation and externalization of PS. Therefore, the $\mathrm{H}_{2} \mathrm{O}_{2}$ generated by both fresh and aged neutrophils following exposure to HBO and pressure may have two functions, firstly to serve as a substrate for MPO to generate other microbiocidal agents, and secondly to trigger pathways that are needed for the clearance of neutrophils. These observations are supported by a marked increase in $\mathrm{H}_{2} \mathrm{O}_{2}$ levels in MDM $\Phi$ that had ingested fresh and aged neutrophils following HBO and pressure treatments. Oxidation of PS may stimulate its externalisation, the possible mechanism being that oxidised PS inhibits aminophospholipid translocase, the enzyme that is responsible for the maintenance of plasma membrane phospholipid asymmetry (Tyurina et al. 2004). These findings are consistent with the previous suggestion of Fadeel et al. (1998) that neutrophils have two pathways for PS externalisation: a caspase-dependent pathway activated during apoptosis and a ROSdependent pathway that is involved in the clearance of activated cells. Patients with chronic granulomatous disease (CGD), whose neutrophils have a defective NADPH oxidase, are characterized by an accumulation of neutrophils at the wound site due to impaired neutrophil apoptosis and clearance (Amulic et al. 2012). This study suggests that a functional NADPH oxidase has a role in neutrophils and macrophages as part of the process of apoptotic cell clearance.

We hypothesized that HBO treatment enhances the clearance of apoptotic neutrophils and thereby elicits a non-inflammatory process. Consistent with this hypothesis it was found that co-culture of aged neutrophils with MDMФ appeared to prevent an increase in the expression of TNF- $\alpha$, a pro-inflammatory cytokine, which was induced in aged neutrophils alone by 
HBO, whereas co-culture of aged neutrophils with MDMФ appeared to induce a large increase in the expression of IL-10, an anti-inflammatory cytokine, above that induced in aged neutrophils alone by HBO. In general, almost the same pattern was seen with both hyperoxia and pressure treatments. IL-10 seems to have a regulatory role in phagocytosis of apoptotic cells (Savill 2000, Fadok et al. 1998, Voll et al. 1997), and it is also a powerful inhibitor of pro-inflammatory cytokine production (Moore et al. 1990, Denys et al. 2002). In addition, it has been shown that the phagocytosis of apoptotic cells by macrophages is associated with suppression of the inflammatory response via decreased production of the pro-inflammatory cytokines such as TNF- $\alpha$ and IL-6 (Voll et al. 1997, Fadok et al. 1998, Savill 2000). Phagocytosis of apoptotic neutrophils is dynamically regulated by the balance between pro- and anti-inflammatory cytokines, specifically TNF- $\alpha$ and IL-10 (Fox et al. 2010). Efficient clearance of apoptotic cells involves contact between the apoptotic cell and the phagocyte, specific recognition and phagocytosis of target. These processes are sufficient to induce profound inhibition of pro-inflammatory cytokine gene expression and secretion by MDMФ (Cvetanovic and Ucker 2004).

\section{Conclusion}

The findings presented here provide evidence that HBO enhances neutrophil engulfment by MDMФ. It is likely that the HBO effects are mediated by the generation of ROS and induction of neutrophil apoptosis that in turn accelerate their uptake by MDMФ. Furthermore, the data demonstrate another aspect in that HBO treatment is able to enhance the removal of apoptotic cells by MDMФ in a non-inflammatory process with increased gene expression of IL-10. Overall, this study provides new insights into the role of HBO in regulation of the phagocytic removal of apoptotic cells, which may prove useful in developing a therapeutic approach to the resolution of inflammation. 


\section{Acknowledgements}

This work was supported by the Iraqi Ministry of Higher Education and Scientific Research

(PhD scholarship to A.J. Almzaiel). Portable hyperbaric chambers were loaned by the British Hyperbaric Association via DDRC Healthcare. 


\section{References}

Al-Waili, S. N. and Butler, G. J. 2006. Effects of hyperbaric oxygen on inflammatory response to wound and trauma: Possible mechanism of action. The Scientific World Journal, $6,425-41$.

Almzaiel, A., Billington, R., Smerdon, G. and Moody, A. J. 2013. Effects of hyperbaric oxygen treatment on antimicrobial function and apoptosis of differentiated HL-60 (neutrophil-like) cells. Life Sci, 93, 125-31.

Amulic, B., Cazalet, C., Hayes, G. L., Metzler, K. D. and Zychlinsky, A. 2012. Neutrophil function: from mechanisms to disease. Annu Rev Immunol, 30, 459-89.

Arroyo, A., Modriansky, M., Serinkan, F. B., Bello, R. I., Matsura, T., Jiang, J., Tyurin, V. A., Tyurina, Y. Y., Fadeel, B. and Kagan, V. E. 2002. NADPH oxidase-dependent oxidation and externalization of phosphatidylserine during apoptosis in Me2SO-differentiated HL-60 cells. Role in phagocytic clearance. J Biol Chem, 277, 49965-75.

Baggiolini, M., Ruch, W., Cooper, P. H. 1986. Measurement of hydrogen peroxide production by phagocytes using homovanillic acid and horseradish peroxidase, Meth Enzymol 132, 395-400.

Benson, R. M., Minter, L. M. and Osborne, B. A. 2003. Hyperbaric oxygen inhibits stimulusinduced proinflammatory cytokine synthesis by human blood-derived monocytemacrophages. Clin Exp Immunol, 134, 57-62.

Bertram, P., Treutner, K. H., Klosterhalfen, B., Arlt, G., Anurov, M., Polivoda, M., Ottinger, A. and Schumpelick, V. 1997. Artificial pressure increase in subcutaneous abscess with evidence of general systemic reaction. Langenbecks Arch Chir, 382, 291-4.

Chen, Y. C., Chen, S. Y., Ho, P. S., Lin, C. H., Cheng, Y. Y., Wang, J. K. and Sytwu, H. K. 2007. Apoptosis of T-leukemia and B-myeloma cancer cells induced by hyperbaric oxygen increased phosphorylation of p38 MAPK. Leuk Res, 31, 805-15.

Counis, M. F. and Torriglia, A. 2000. DNases and apoptosis. Biochem Cell Biol, 78, 405-14.

Cvetanovic, M. and Ucker, D. S. 2004. Innate immune discrimination of apoptotic cells: repression of proinflammatory macrophage transcription is coupled directly to specific recognition. J Immunol, 172, 880-9.

Denys, A., Udalova, I. A., Smith, C., Williams, L. M., Ciesielski, C. J., Campbell, J., Andrews, C., Kwaitkowski, D. and Foxwell, B. M. 2002. Evidence for a dual mechanism for IL-10 suppression of TNF-alpha production that does not involve inhibition of p38 mitogenactivated protein kinase or NF-kappa B in primary human macrophages. J Immunol, 168, 4837-45.

Fadeel, B., Ahlin, A., Henter, J. I., Orrenius, S. and Hampton, M. B. 1998. Involvement of caspases in neutrophil apoptosis: regulation by reactive oxygen species. Blood, 92, 4808-18.

Fadok, V. A., Bratton, D. L. and Henson, P.M. 2001a. Phagocyte receptors for apoptotic cells: recognition, uptake, and consequences. J Clin Invest, 108, 957-62. 
Fadok, V. A., De Cathelineau, A., Daleke, D. L., Henson, P. M. and Bratton, D. L. 2001 b. Loss of phospholipid asymmetry and surface exposure of phosphatidylserine is required for phagocytosis of apoptotic cells by macrophages and fibroblasts. J Biol Chem, 276, 1071-7.

Fadok, V. A., Bratton, D. L., Konowal, A., Freed, P. W., Westcott, J. Y. and Henson, P. M. 1998. Macrophages that have ingested apoptotic cells in vitro inhibit proinflammatory cytokine production through autocrine/paracrine mechanisms involving TGF-beta, PGE2, and PAF. J Clin Invest, 101, 890-8.

Fadok, V. A., Savill, J. S., Haslett, C., Bratton, D. L., Doherty, D. E., Campbell, P. A. and Henson, P. M. 1992. Different populations of macrophages use either the vitronectin receptor or the phosphatidylserine receptor to recognize and remove apoptotic cells. J Immunol, 149, 4029-35.

Filipski, J., Leblanc, J., Youdale, T., Sikorska, M. and Walker, P. R. 1990. Periodicity of DNA folding in higher order chromatin structures. EMBO J, 9, 1319-27.

Fox, S., Leitch, A. E., Duffin, R., Haslett, C. and Rossi, A. G. 2010. Neutrophil apoptosis: relevance to the innate immune response and inflammatory disease. J Innate Immun, 2, 21627.

Ganguly, B. J., Tonomura, N., Benson, R. M., Osborne, B. A. and Granowitz, E. V. 2002. Hyperbaric oxygen enhances apoptosis in hematopoietic cells. Apoptosis, 7, 499-510.

Gill, A. L. and Bell, C. N. A. 2004. Hyperbaric oxygen: its uses, mechanisms of action and outcomes. QJM, 97, 385-95.

Hampton, M. B., Vissers, M. C., Keenan, J. I. and Winterbourn, C. C. 2002. Oxidantmediated phosphatidylserine exposure and macrophage uptake of activated neutrophils: possible impairment in chronic granulomatous disease. J Leukoc Biol, 71, 775-81.

Hart, S. P., Dougherty, G. J., Haslett, C. and Dransfield, I. 1997. CD44 regulates phagocytosis of apoptotic neutrophil granulocytes, but not apoptotic lymphocytes, by human macrophages. J Immunol, 159, 919-25.

Henson, P. M. and Johnston, R. B., Jr. 1987. Tissue injury in inflammation. Oxidants, proteinases, and cationic proteins. J Clin Invest, 79, 669-74.

Kasahara, Y., Iwai, K., Yachie, A., Ohta, K., Konno, A., Seki, H., Miyawaki, T. and Taniguchi, N. 1997. Involvement of reactive oxygen intermediates in spontaneous and CD95 (Fas/APO-1)-mediated apoptosis of neutrophils. Blood, 89, 1748-53.

Khanna, S., Biswas, S., Shang, Y., Collard, E., Azad, A., Kauh, C., Bhasker, V., Gordillo, G. M., Sen, C. K. and Roy, S. 2010. Macrophage dysfunction impairs resolution of inflammation in the wounds of diabetic mice. PLoS One, 5, e9539.

Lahat, N., Bitterman, H., Yaniv, N., Kinarty, A. and Bitterman, N. 1995. Exposure to hyperbaric oxygen induces tumour necrosis factor-alpha (TNF-alpha) secretion from rat macrophages. Clin Exp Immunol, 102, 655-9.

Lee, A., Whyte, M. K. and Haslett, C. 1993. Inhibition of apoptosis and prolongation of neutrophil functional longevity by inflammatory mediators. J Leukoc Biol, 54, 283-288. 
Mateo, V., Brown, E. J., Biron, G., Rubio, M., Fischer, A., Deist, F. L. and Sarfati, M. 2002. Mechanisms of CD47-induced caspase-independent cell death in normal and leukemic cells: link between phosphatidylserine exposure and cytoskeleton organization. Blood, 100, 288290 .

Matsunami, T., Sato, Y., Hasegawa, Y., Ariga, S., Kashimura, H., Sato, T. and Yukawa, M. 2011. Enhancement of reactive oxygen species and induction of apoptosis in streptozotocininduced diabetic rats under hyperbaric oxygen exposure. Int J Clin Exp Pathol, 4, 255-66.

Mecklenburgh, K. I., Walmsley, S. R., Cowburn, A. S., Wiesener, M., Reed, B. J., Upton, P. D., Deighton, J., Greening, A. P. and Chilvers, E. R. 2002. Involvement of a ferroprotein sensor in hypoxia-mediated inhibition of neutrophil apoptosis. Blood, 100, 3008-16.

Moore, K. W., Vieira, P., Fiorentino, D. F., Trounstine, M. L., Khan, T. A. and Mosmann, T. R. 1990. Homology of cytokine synthesis inhibitory factor (IL-10) to the Epstein-Barr virus gene BCRFI. Science, 248, 1230-4.

Quinn, M. T., Deleo, F. R. and Bokoch, G. M. 2007. Nutrophil methods and protocols, New Jersy, USA, Human Press Totowa, Nw Jersy, 21-25

Rollet-Labelle, E., Grange, M. J., Elbim, C., Marquetty, C., Gougerot-Pocidalo, M. A. and Pasquier, C. 1998. Hydroxyl radical as a potential intracellular mediator of polymorphonuclear neutrophil apoptosis. Free Radic Biol Med, 24, 563-72.

Rossi, A. G., Sawatzky, D. A., Walker, A., Ward, C., Sheldrake, T. A., Riley, N. A., Caldicott, A., Martinez-Losa, M., Walker, T. R., Duffin, R., Gray, M., Crescenzi, E., Martin, M. C., Brady, H. J., Savill, J. S., Dransfield, I. and Haslett, C. 2006. Cyclin-dependent kinase inhibitors enhance the resolution of inflammation by promoting inflammatory cell apoptosis. Nat Med, 12, 1056-64.

Savill, J. 2000. Apoptosis in resolution of inflammation. Kidney Blood Press Res, 23, 173-4.

Savill, J. S., Wyllie, A. H., Henson, J. E. and Haslett, C. 1989. Macrophage phagocytosis of aging neutrophils in inflammation. Journal of Clinical Investagations, 83, 865-875.

Scheel-Toellner, D., Wang, K., Craddock, R., Webb, P. R., Mcgettrick, H. M., Assi, L. K., Parkes, N., Clough, L. E., Gulbins, E., Salmon, M. and Lord, J. M. 2004. Reactive oxygen species limit neutrophil life span by activating death receptor signaling. Blood, 104, 25572564.

Serhan, C. N. and Savill, J. 2005. Resolution of inflammation: the beginning programs the end. Nat Immunol, 6, 1191-7.

Shiratsuchi, H. and Basson, M. D. 2004. Extracellular pressure stimulates macrophage phagocytosis by inhibiting a pathway involving FAK and ERK. Am J Physiol Cell Physiol, 286, C1358-66.

Simon, H. U. 2003. Neutrophil apoptosis pathways and their modifications in inflammation. Immunol Rev, 193, 101-10.

Tandara, A. A. and Mustoe, T. A. 2004. Oxygen in wound healing-more than a nutrient. World J Surg, 28, 294-300. 
Tyurina, Y. Y., Tyurin, V. A., Zhao, Q., Djukic, M., Quinn, P. J., Pitt, B. R. and Kagan, V. E. 2004. Oxidation of phosphatidylserine: a mechanism for plasma membrane phospholipid scrambling during apoptosis? Biochem Biophys Res Commun, 324, 1059-64.

van Den Berg, J. M., Weyer, S., Weening, J. J., Roos, D. and Kuijpers, T. W. 2001. Divergent effects of tumor necrosis factor \{alpha\} on apoptosis of human neutrophils. J Leukoc Biol, 69, 467-473.

van Engeland, M., Kuijpers, H. J., Ramaekers, F. C., Reutelingsperger, C. P. and Schutte, B. 1997. Plasma membrane alterations and cytoskeletal changes in apoptosis. Exp Cell Res, 235, 421-30.

van Engeland, M., Nieland, L. J., Ramaekers, F. C., Schutte, B. and Reutelingsperger, C. P. 1998. Annexin V-affinity assay: a review on an apoptosis detection system based on phosphatidylserine exposure. Cytometry, 31, 1-9.

Vistica, D. T., Skehan, P., Scudiero, D., Monks, A., Pittman, A. and Boyd, M. R. 1991. Tetrazolium-based assays for cellular viability: a critical examination of selected parameters affecting formazan production. Cancer Res, 51, 2515-20.

Voll, R. E., Herrmann, M., Roth, E. A., Stach, C., Kalden, J. R. and Girkontaite, I. 1997. Immunosuppressive effects of apoptotic cells. Nature, 390, 350-1.

Walmsley, S. R., Print, C., Farahi, N., Peyssonnaux, C., Johnson, R. S., Cramer, T., Sobolewski, A., Condliffe, A. M., Cowburn, A. S., Johnson, N. and Chilvers, E. R. 2005. Hypoxia-induced neutrophil survival is mediated by HIF-1alpha-dependent NF-kappaB activity. J Exp Med, 201, 105-15.

Weber, S. U., Koch, A., Kankeleit, J., Schewe, J. C., Siekmann, U., Stuber, F., Hoeft, A. and Schroder, S. 2009a. Hyperbaric oxygen induces apoptosis via a mitochondrial mechanism. Apoptosis, 14, 97-107.

Werner, S. and Grose, R. 2003. Regulation of Wound Healing by Growth Factors and Cytokines. Physiol. Rev., 83, 835-70.

Wolcott, R. D, Rhoads, D. D. and Dowd, S. E. 2008. Biofilms and chronic wound inflammation. J Wound Care 17, 333-41.

Wyllie, A. H.,Kerr, J. F. and Currie, A. R. 1980. Cell death: the significance of apoptosis. Int Rev Cytol, 68, 251-306.

Zhang, Q., Chang, Q., Cox, R. A., Gong, X. and Gould, L. J. 2008. Hyperbaric oxygen attenuates apoptosis and decreases inflammation in an ischemic wound model. J Invest Dermatol, 128, 2102-12. 


\section{Figure Legends}

Fig. 1 Neutrophil cell viability (\% relative to normoxia) after pre-treatment with hypoxia, hyperoxia, pressure and HBO. Neutrophils were isolated from bovine blood and exposed to a range of oxygen and pressure conditions for 90 min (Section 2.4). After exposure, cells were washed, then immediately assayed or aged for $22 \mathrm{~h}$ to induce apoptosis. Cell viability was assessed using trypan blue (A) or MTT (B). Data are expressed as means \pm SEM for three separate experiments with triplicate measurements $(n=3)$. Results are normalised against viability of fresh neutrophils pre-treated with normoxia for both trypan blue and MTT assays; for both fresh and aged neutrophils. * indicate significant differences between fresh and aged neutrophils after the same treatment. Treatments with the same lower case letter are not significantly different, whereas those with different lower case letters are significantly different (ANOVA, $P<0.05$ ).

Fig. 2 Neutrophil populations after pre-treatment with normoxia, hypoxia, hyperoxia, pressure and HBO. Neutrophils were isolated from bovine blood and exposed to a range of oxygen and pressure conditions for $90 \mathrm{~min}$ (see Section 2.4). After exposure, cells were washed, and then assayed immediately (fresh neutrophils) (A) or aged for $22 \mathrm{~h}$ to induce apoptosis (B). The proportions of dead, viable, late and early apoptotic neutrophils were assessed by flow cytometry after staining with both FITC-conjugated annexin V and PI (as described in Section 2.10). Data are expressed as means \pm SEM for three separate experiments $(n=3)$ with triplicate measurements. * significant difference versus treatment with normoxia (one-way ANOVA or Kruskal-Wallis, $P<0.05$ ).

Fig. 3 Morphological analysis of apoptosis by light microscopy in neutrophils pre-treated with normoxia, hypoxia, hyperoxia, pressure and HBO. Neutrophils were isolated from bovine blood and exposed to a range of oxygen conditions for $90 \mathrm{~min}$ (Section 2.4). After exposure, cells were washed, and then assayed immediately (fresh neutrophils) or aged for 22 
$\mathrm{h}$ to induce apoptosis before assay. Cytospin preparations (500 $\mathrm{g}$ for $5 \mathrm{~min}$ ) of neutrophils stained with Wright-Giemsa stain were then examined. Light microscopy of neutrophils (A) showing morphological changes in fresh and 22 h-aged neutrophils after exposure to normoxia and HBO. Neutrophils were characterised by their multi-lobed nuclei (upper left panel). Bold arrows indicate nuclear and cytoplasmic condensation and fragmentation. After pre-treatment with $\mathrm{HBO}$ there was a higher percentage of cells with typical features of apoptosis compared to those pre-treated with normoxia (B). Data are expressed as means \pm SEM for three separate experiments with triplicate measurements $(n=3)$. Treatments with the same lower case letter are not significantly different, whereas those with different lower case letters are significantly different (two-way ANOVA, $P<0.05$ ).

Fig. 4 Examples of the electrophoretic ladder pattern of DNA fragmentation from neutrophils pre-treated with normoxia, hypoxia, hyperoxia, pressure and HBO. Neutrophils were isolated from bovine blood and exposed to a range of oxygen and pressure conditions for $90 \mathrm{~min}$ (Section 2.4). After exposure, cells were washed, and then assayed immediately (fresh neutrophils) (A) or aged for $22 \mathrm{~h}$ to induce apoptosis before assay (B). The DNA was extracted from cells (as described in Section 2.11) run on $1 \%$ agarose gels containing SYBR ${ }^{\circledR}$ Safe $(1 \times), 20$ ng per lane, and visualized under UV.

Fig. 5 Flow cytometry analysis of phagocytosis of neutrophils by MDM $\Phi$ after pre-treatment of the neutrophils with normoxia, hypoxia, hyperoxia, pressure and HBO. Neutrophils (either fresh or $22 \mathrm{~h}$ aged) were labelled with $\operatorname{Tracker}^{\mathrm{TM}}$ Green and co-cultured with MDMФ, after which they were exposed to a range of oxygen and pressure conditions for $90 \mathrm{~min}$ (Section 2.4). Cells were washed and analysed using flow cytometry. The results are presented as the percentage of MDMФ that had ingested neutrophils. Data are expressed as means $\pm \mathrm{SEM}$ for three separate experiments $(n=3)$ with triplicate measurements. Treatments with the same 
lower case letter are not significantly different, whereas those with different lower case letters are significantly different (two-way ANOVA, $P<0.05$ ).

Fig. 6 Light microscopic detection of phagocytosis of neutrophils by MDM $\Phi$ after pretreatment of the neutrophils with normoxia, hypoxia, hyperoxia, pressure and HBO. Fresh or 22 h-aged neutrophils neutrophils were co-cultured with MDMФ and exposed to a range of oxygen conditions for $90 \mathrm{~min}$ (Section 2.4). After exposure, cells were washed, fixed and stained for MPO, and then were analysed using light microscopy. Light microscopic analysis demonstrating MDMФ that had engulfed apoptotic neutrophils for both fresh and $22 \mathrm{~h}$-aged neutrophils after exposure to HBO or normoxia. MDMФ that had ingested neutrophils contain a yellow-brown reaction product (MPO-positive cells). MDMФ that had not ingested neutrophils were MPO-negative (A). Results are presented as the percentage of MDMФ that had ingested neutrophils (B). Data are expressed as means \pm SEM for three separate experiments $(n=3)$ with triplicate measurements. Treatments with the same lower case letter are not significantly different, whereas those with different lower case letters are significantly different (two-way ANOVA, $P<0.05$.

Fig. $7 \mathrm{H}_{2} \mathrm{O}_{2}$ release by isolated neutrophils and MDMФ that had ingested neutrophils after exposure to normoxia, hypoxia, hyperoxia, pressure and HBO. Neutrophils were isolated from bovine blood exposed to a range of oxygen and pressure conditions for 90 min (Section 2.4). After exposure, fresh or $22 \mathrm{~h}$-aged neutrophils were assayed after stimulation with 100 ng $\mathrm{ml}^{-1}$ PMA (A). For co-culture experiments (B) fresh or $22 \mathrm{~h}$-aged neutrophils were stimulated with PMA, incubated with MDMФ and exposed to a range of conditions for 90 min. $\mathrm{H}_{2} \mathrm{O}_{2}$ levels in the medium were determined in both neutrophils and MDMФ that had ingested neutrophils using HRP/homovanillic acid (Section 2.14). These are expressed as the amount of $\mathrm{H}_{2} \mathrm{O}_{2}$ produced per $10^{6}$ cells. Data are means \pm SEM for three separate experiments $(n=3)$ measured in triplicate. Treatments with the same lower case letter are not 
significantly different, whereas those with different lower case letters are significantly different (two-way ANOVA, $P<0.05$ ).

Fig. 8 TNF- $\alpha$ and IL-10 expression by neutrophils and MDM $\Phi$ that had ingested neutrophils after treatment with normoxia, hypoxia, hyperoxia, pressure and HBO. Neutrophils isolated from bovine blood were exposed to a range of oxygen and pressure conditions for $90 \mathrm{~min}$ (Section 2.4). After exposure, fresh or 22 h-aged neutrophils) were stimulated with $100 \mathrm{ng}$ $\mathrm{ml}^{-1}$ LPS and assayed (A and B). For co-culture experiments (C and D) fresh or $22 \mathrm{~h}$-aged neutrophils were incubated with LPS-stimulated MDMФ and exposed to a range of oxygen and pressure conditions for $90 \mathrm{~min}$ and assayed. qPCR was used to determine RNA expression under different treatments, and expression was normalised against endogenous controls. Gene expression under different treatments is expressed as a fold change in expression versus fresh neutrophils under normoxia (A and B) or MDMФ cultured alone (C and D). Data are means \pm SEM for three separate experiments measured in triplicate $(n=3)$. For fresh neutrophils, treatments with the same lower case letter are not significantly different, whereas those with different lower case letters are significantly different (KruskalWallis, $P<0.05)$. For aged neutrophils, the same is indicated using lower case italic letters. 

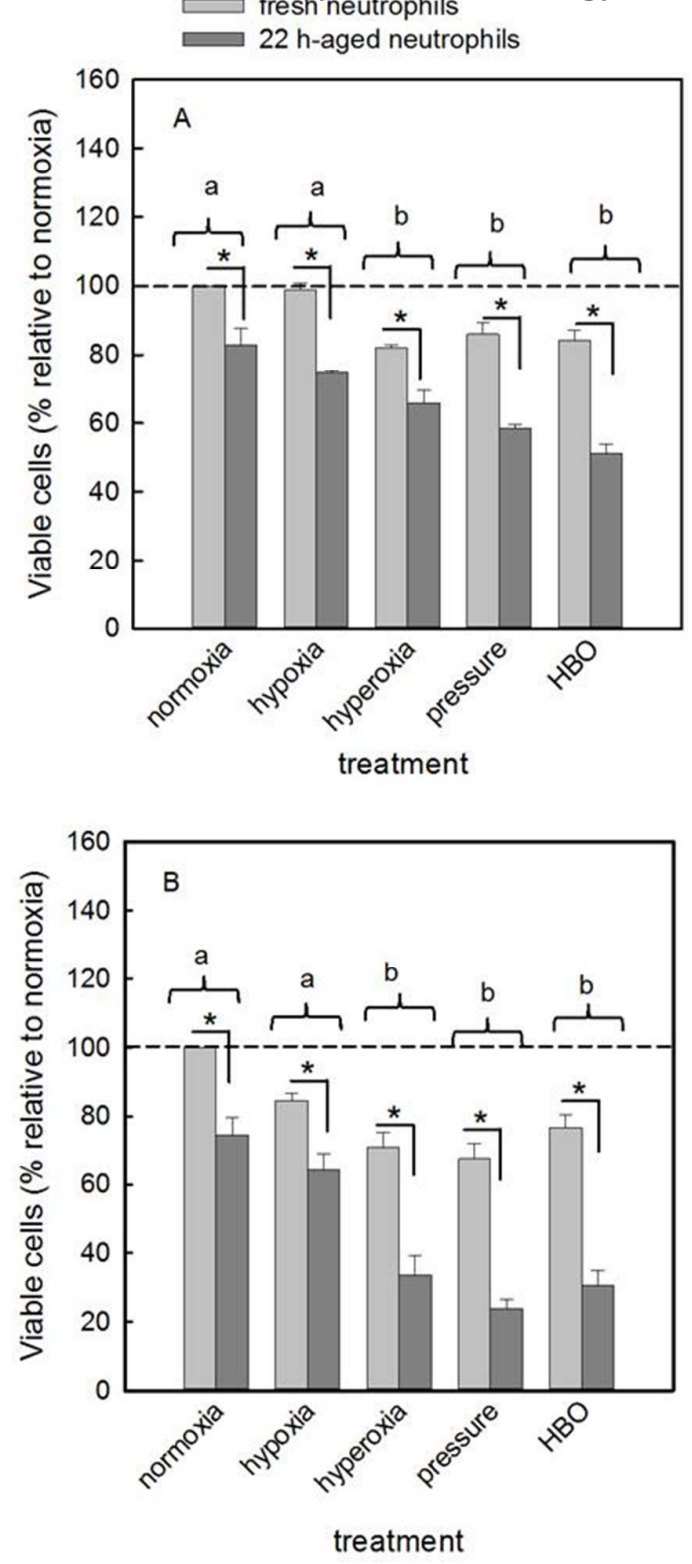

Figure 1 
$\square \%$ live cells

$\square$ early apoptotic cells

$\square \%$ late apoptotic cells

\% dead cells
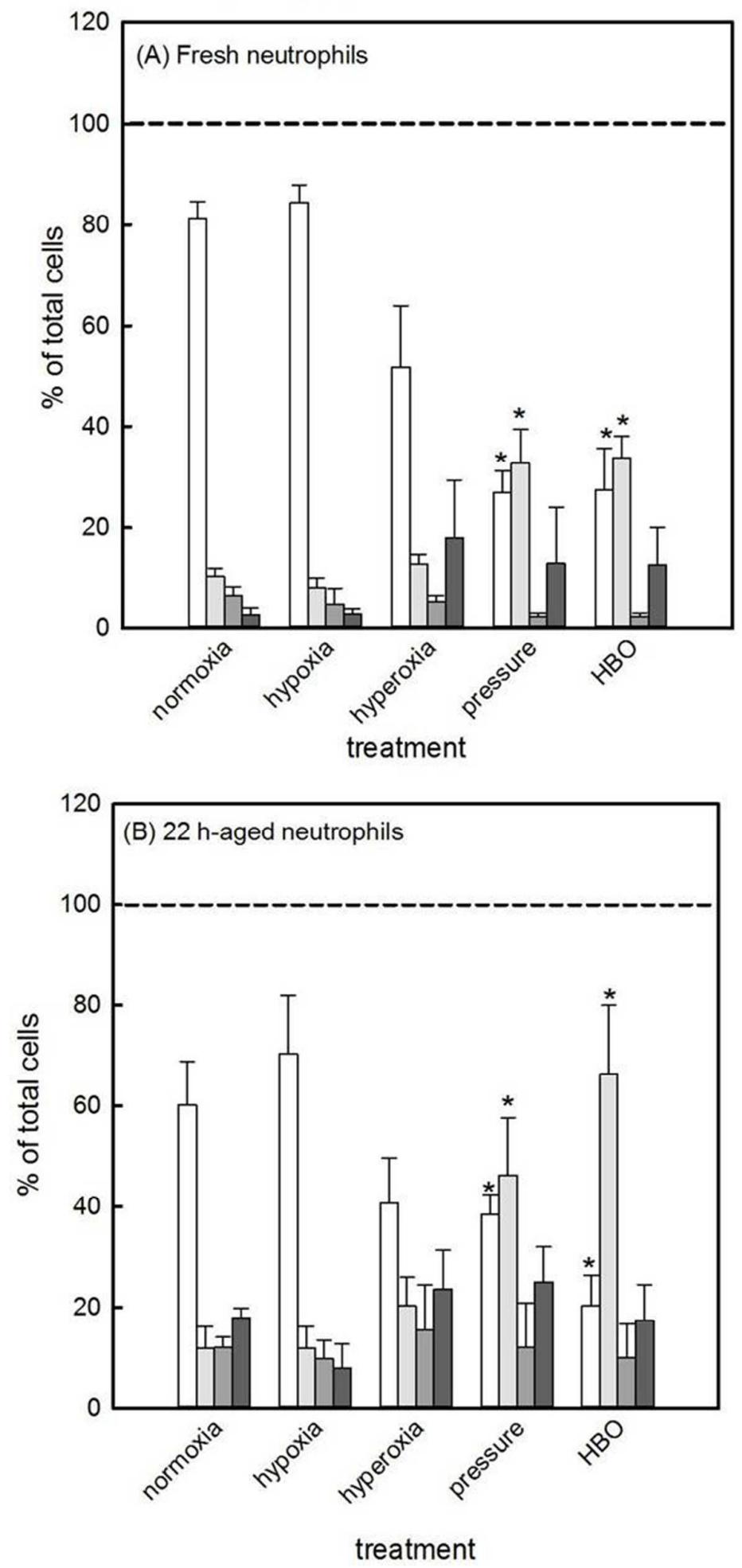

Figure 2 

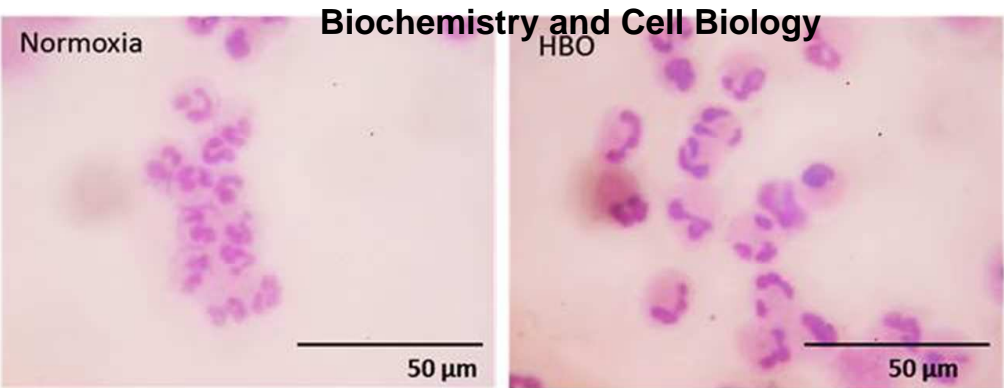

fresh

neutrophils
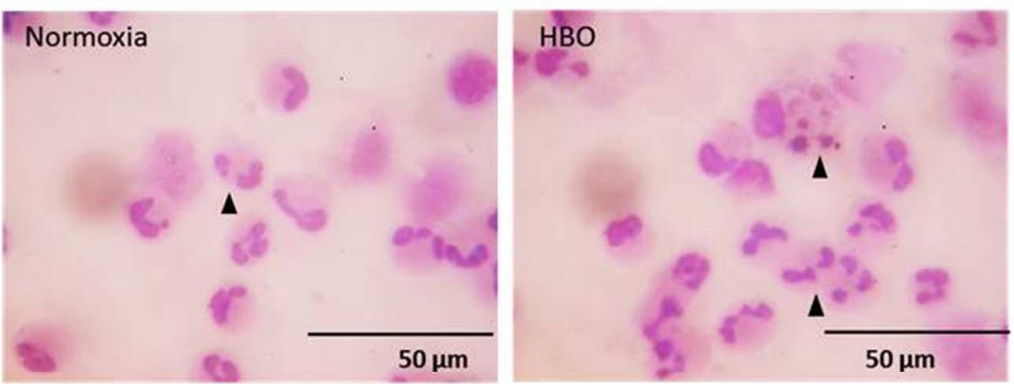

$22 \mathrm{~h}$-aged neutrophils

fresh neutrophils

22 h-aged neutrophils

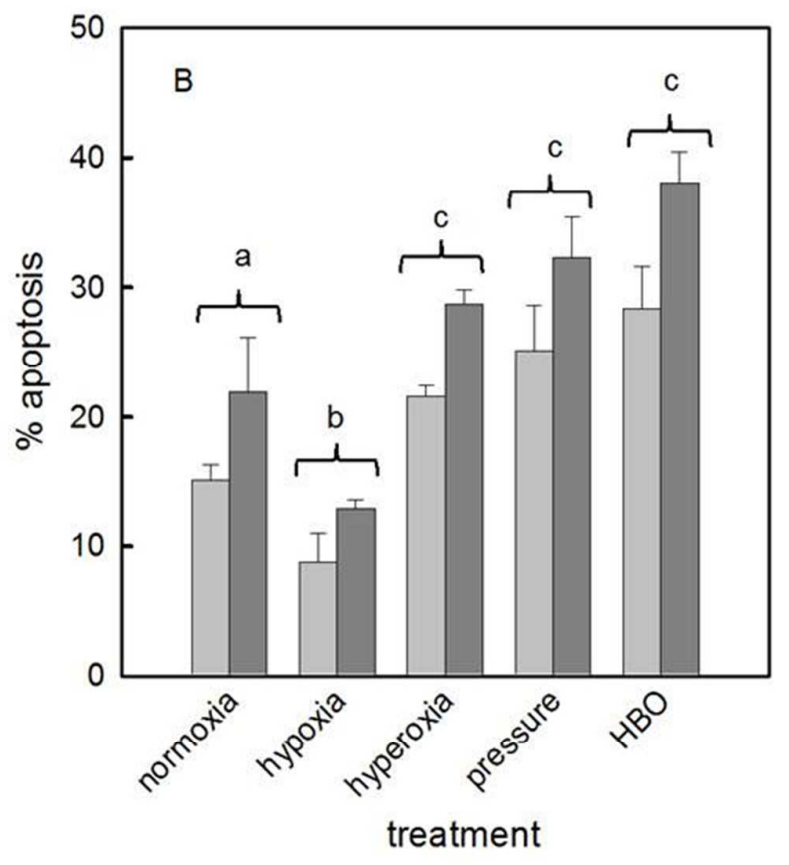

Figure 3 


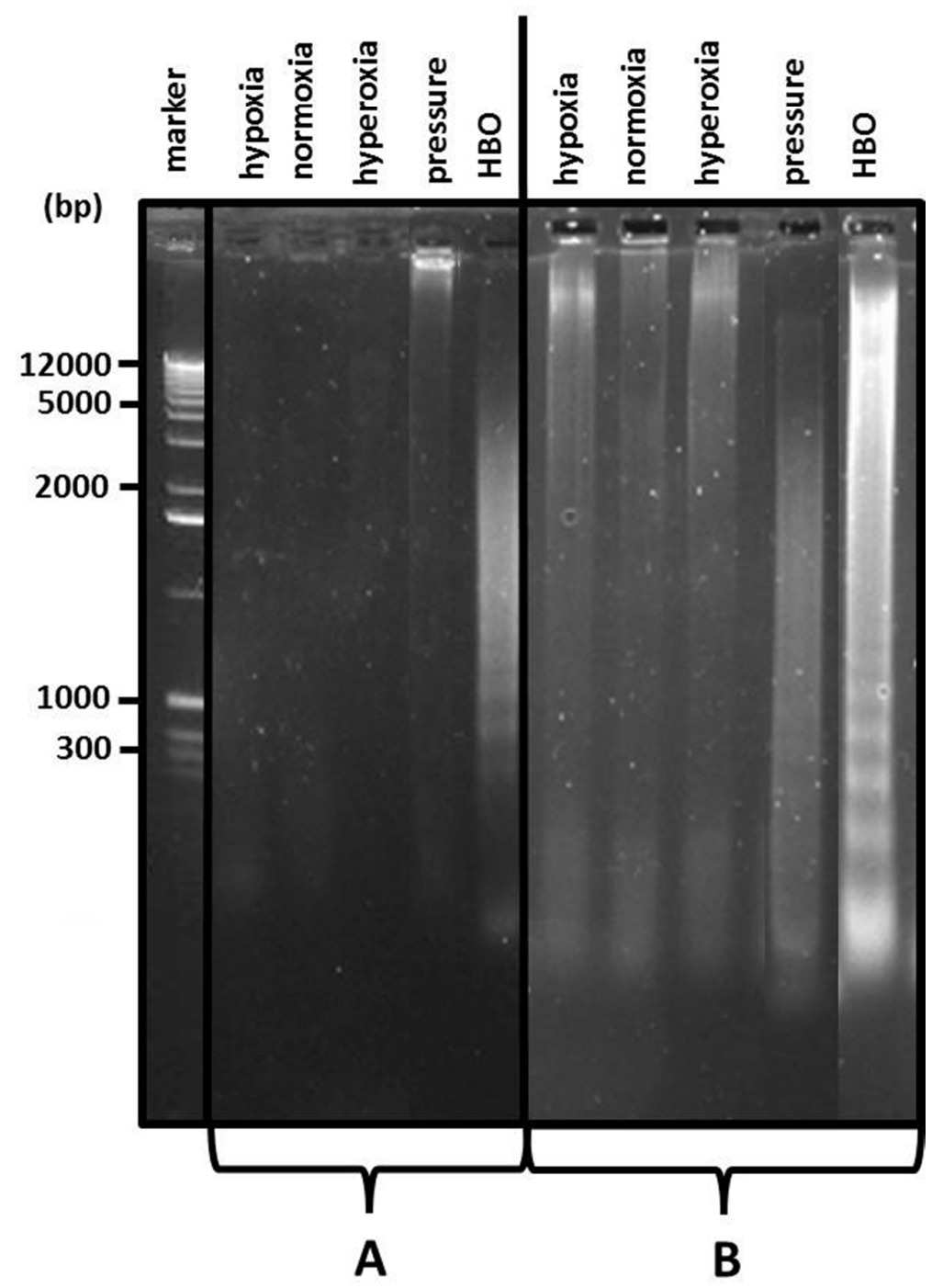

Figure 4 
$\square 22 \mathrm{~h}$-aged neutrophils

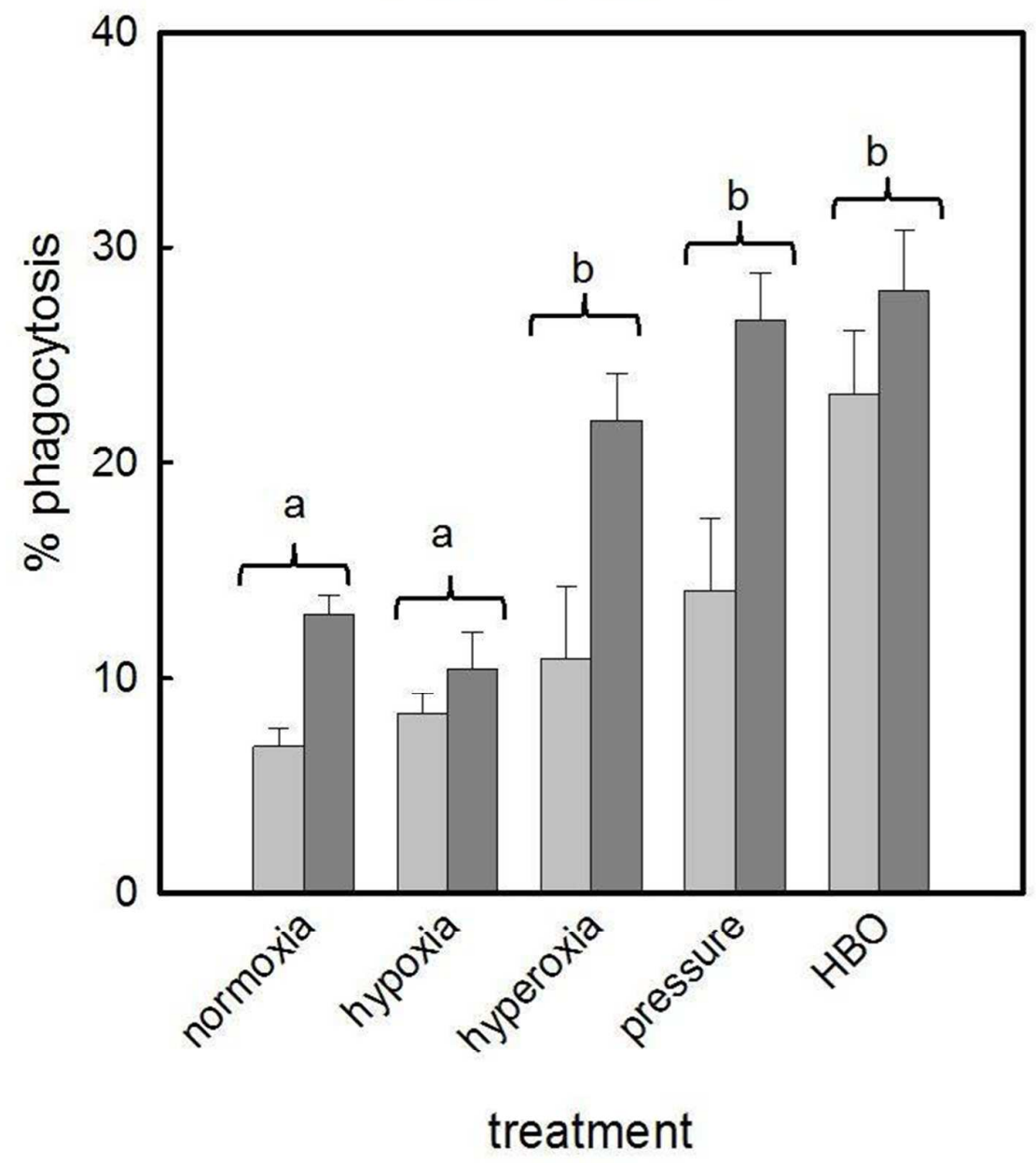

Figure 5 


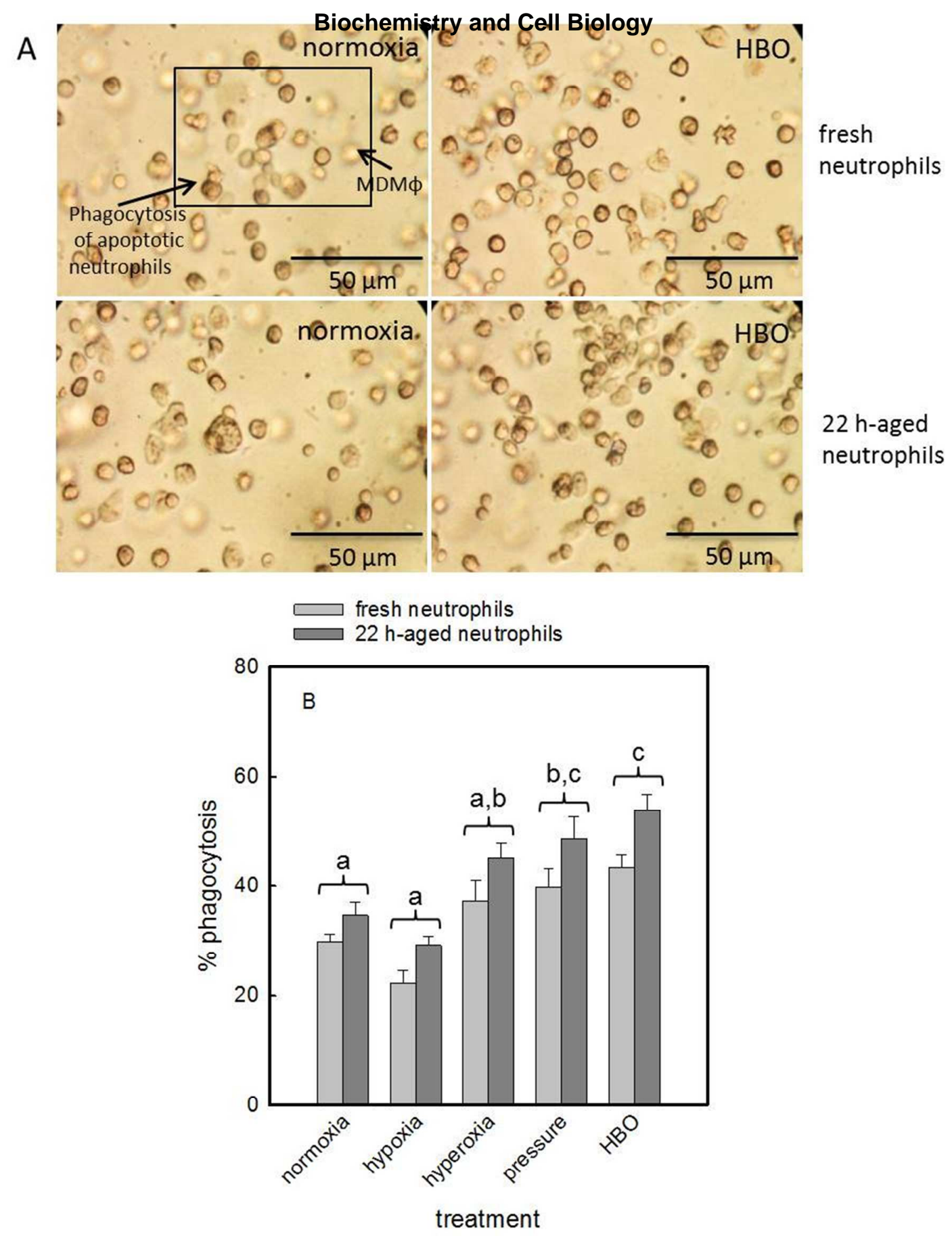

Figure 6 

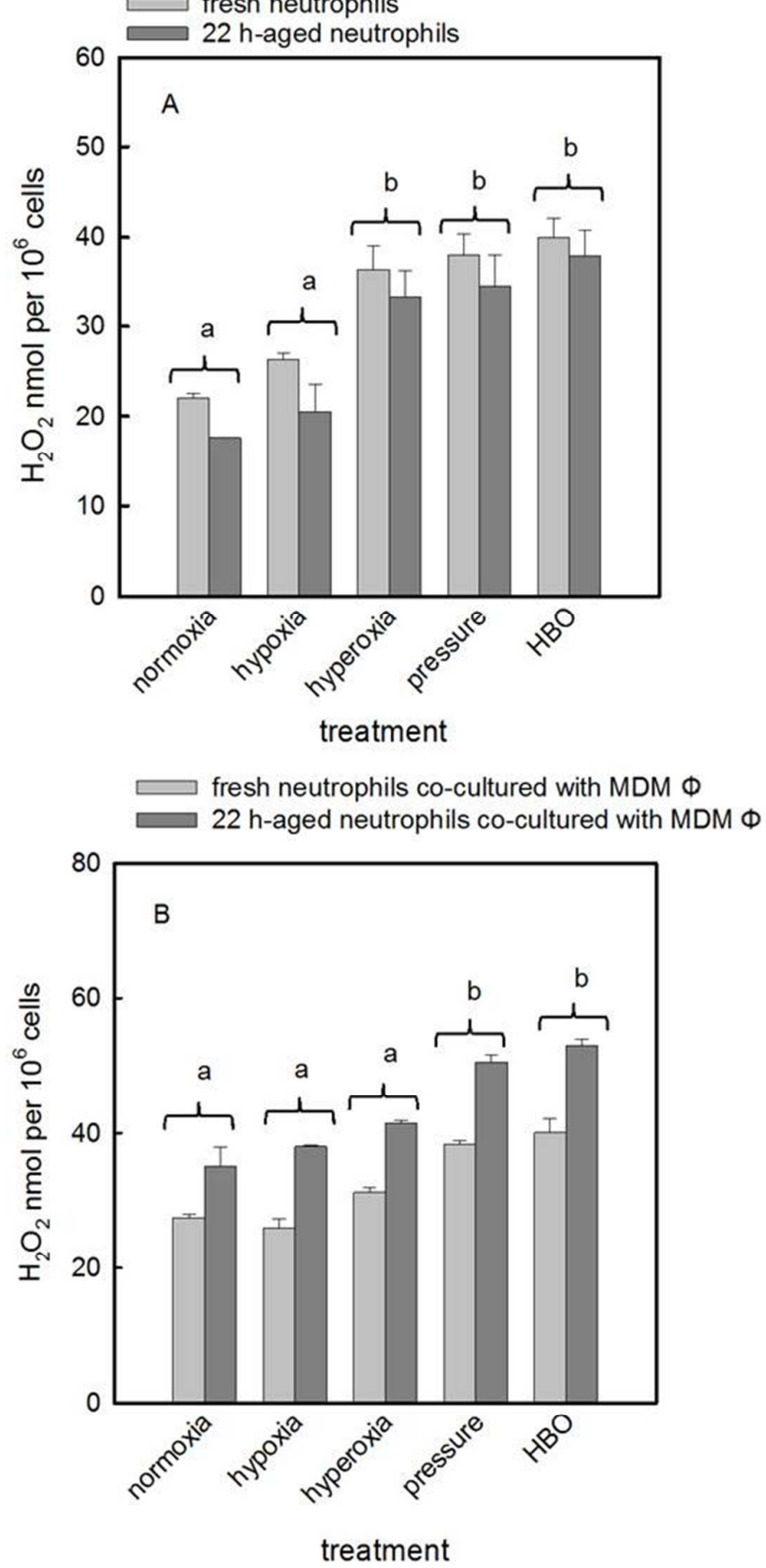

Figure 7 

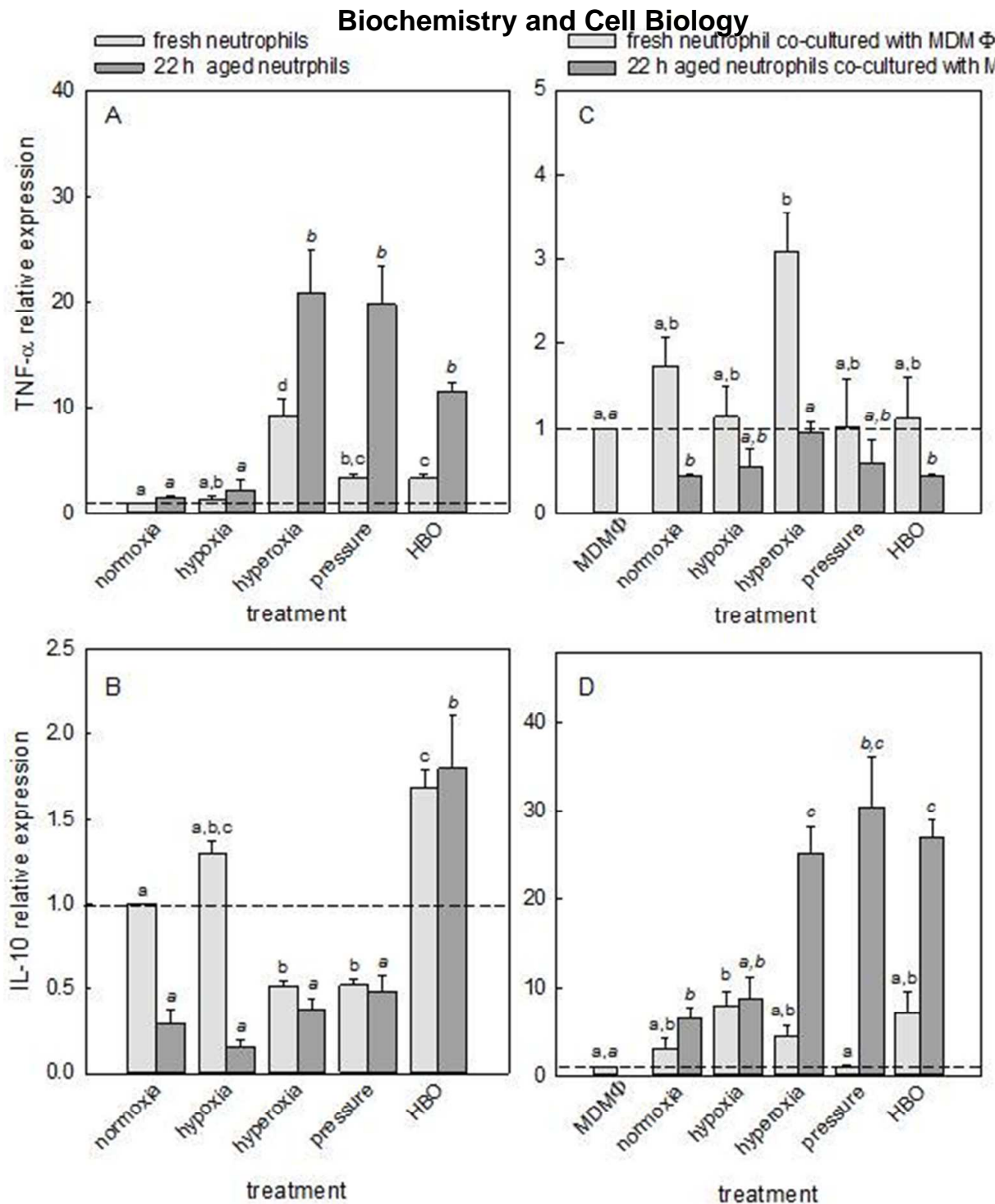

Figure 8 